\title{
Hear Me Write: Does CEO Narcissism Affect Disclosure?
}

By

\author{
Gilberto Marquez-Illescas ${ }^{\mathrm{a}}$, Allan A. Zebedee ${ }^{\mathrm{b},{ }^{*}}$, Linying Zhou ${ }^{\mathrm{c}}$ \\ ${ }^{a}$ School of Business, Clarkson University, 8 Clarkson Ave 13699, Potsdam, NY, United States of \\ America. Email address: gmarquez@clarkson.edu, Tel: (1)315-268-3814, Fax: (1)315-268-3810. \\ ${ }^{\mathrm{b}}$ School of Business, Clarkson University, 8 Clarkson Ave 13699, Potsdam, NY, United States of \\ America and Center for Economics, Finance and Management Studies, Hunan University, China. \\ Email address: azebedee@clarkson.edu, Tel: (1) 315-268-3890, Fax: (1) 315-268-3810. \\ ${ }^{c}$ College of Business Administration, California State University - San Marcos, 333 S. Twin Oaks \\ Valley Rd., San Marcos, CA, United States of America. Email address: jzhou@csusm.edu, Tel: \\ (1) $760-750-4000$. \\ ${ }^{*}$ Corresponding Author.
}




\title{
Hear Me Write: Does CEO Narcissism Affect Disclosure?
}

\begin{abstract}
:
Through earnings announcements, conference calls, and other press releases, corporate executives have an opportunity to frame the narrative of financial disclosures. Numerous studies have shown that textual tone significantly influences stock returns, suggesting that through word choice, upper management may impact market reaction. In this study, we examine the influence of CEO personality traits on corporate disclosures by analyzing the tone of earnings announcements for a sample of Fortune 500 CEOs over nearly two decades. Our hypotheses are two-fold: 1) that qualitative disclosures in firms with narcissistic leaders will be biased upward and 2) the bias will moderate as CEOs becomes older. Our empirical results support these hypotheses and suggest that more narcissistic CEOs tend to reinforce their grandiose self-image by issuing more positive earnings announcements but this desire wanes with CEO age. We also find that the stock market response to the tone of the earnings announcement is less pronounced for more narcissistic CEOs, suggesting the market takes into account the bias in narcissistic CEO announcements.
\end{abstract}

Keywords: CEO; CEO age; earnings announcements; narcissism; textual analysis. 


\section{Introduction}

Chief Executive Officers (CEOs) are afforded unique opportunities to provide analyses and discussions to investors through conference calls, earnings announcements, and other filings through the Securities and Exchange Commission (SEC). These disclosures are less regulated than annual filings and thus, they allow the CEOs more freedom to express individual opinions and to frame the narrative with stakeholders. Given the importance of this dialogue, market watchers and researchers have invested significant effort in interpreting the text of these various corporate announcements (e.g., Henry 2008; Feldman et al. 2010; Li 2010; Davis and Tama-Sweet 2012; Davis et al. 2012). Studies have found that tone is not only affected by the objective corporate financial performance (Schleicher and Walker 2010; Clatworthy and Jones 2003), but also by management ability (Luo and Zhou 2017), CEOs' compensation structure (Arslan-Ayaydin et al. 2016), and their dispositional optimism (Davis et al. 2015). Likewise, numerous studies have also documented that positive tone of these disclosures significantly increases stock returns in the short term (e.g., Price et al. 2012; Jegadeesh and Wu 2013), but leads to negative stock returns in the longer-term (Huang et al. 2014). Altogether, these prior findings indicate that CEOs exert an influence on the tone of the financial disclosures and that market agents react to such tone. Therefore, whether a conscious choice or not, CEOs inflating the tone is against the objective of neutrally presenting financial performance; in this regard, inflating the tone has a similar effect to the stock market with other behaviors such as overstating revenue or asset. CEOs inflating the tone has a detrimental effect on shareholders' wealth, similar to other behaviors such as misreporting of financial information. Hence, from a business ethics perspective, we consider that it is important to identify more determinants of corporate disclosure tone in the hope of better informing investors. Consistent with prior business research (e.g., O'Reilly III et al. 2017) suggesting that narcissism might be a personality trait affecting CEO's propensity to engage in unethical practices, such as white collar crime (e.g., Blickle et al. 2006), tax avoidance (Olsen and Stekelberg 2016), or manipulation of financial information (e.g., Ham et al. 2017), this study proposes 
that more narcissistic CEOs will tend to inflate the tone of the earnings announcements and that this this narcissism-driven positive bias is likely to be moderated by CEO age.

Self-enhancement is one of the most important characteristics of narcissism (e.g., Campbell et al. 2000). Consistent with this notion, more narcissistic individuals usually have a highly positive self-view (e.g. Horvath and Morf 2010). Prior social psychology research indicates that more narcissistic individuals tend to describe their professional performance and physical appearance in a more positive way because this allows them to feed or reinforce their impressive self-image (e.g., Gabriel et al. 1994; John and Robins 1994; Farwell and Wohlwend-Lloyd 1998). Our study conjectures that more narcissistic CEOs are likely to describe their firm performance in earnings announcements more positively compared to their less narcissistic counterparts in line with the 'rosy' view of their own self-perception. Earnings announcements are a naturally good outlet for investigating this conjecture because their periodicity provides CEOs with a continual opportunity to reinforce their self-important image (Amenic and Craig 2010). Furthermore, we argue that CEO age moderates the influence of narcissism on the tone of earnings announcements; such influence is smaller when CEOs are older. Recent social psychology research (e.g., Ashton and Lee 2016) suggests that some personality features that can reduce the exaggerated positive self-view attributed to narcissism (e.g., humility and conscientiousness) are likely to develop with age. Thus, we expect the effect of CEO narcissism on the tone of the earnings announcements to be less salient as CEO age increases. Therefore, there are two main testable hypotheses in this study. First, there should be a positive effect of CEO narcissism on tone of earnings announcements; second, the positive impact is likely to be lower in a firm led by an older CEO.

This paper tests these two main conjectures in a sample consisting of 215 firms and 280 CEOs with 3,377 unique firm-CEO-quarter observations ranging from 1996 to 2014. We use tone data from Wharton Research Data Services (WRDS) SEC Analytics Suite, financial data from Compustat, stock return data from Center for Research in Security Prices (CRSP), and analysts' data from Thomson Reuters Institutional Brokers' Estimate System (I/B/E/S). A narcissism score is calculated on the basis of (1) the size of the 
CEO's picture in annual reports, (2) cash compensation for CEO relative to highest paid non-CEO executive, and (3) non-cash compensation for CEO relative to highest paid non-CEO executive (Olsen et al. 2014; Olsen and Stekelberg 2016). Our empirical results confirm the proposed hypotheses; namely, we find in our data that CEO's narcissism exerts a significant and positive effect on the tone of earnings announcements, and this effect is smaller in firms led by an older CEO.

This study ties together two strands of active research: CEO narcissism levels and textual analysis of corporate disclosures. Over the last two decades, the business literature has documented an increase in the narcissism levels among corporate executives (e.g., Campbell and Campbell 2009; Engelen et al. 2016). This is highly relevant because narcissism affects firm decisions. For example, Chaterjee and Hambrick (2007) show that firms with more narcissistic CEOs are likely to employ bolder strategies. The effect of narcissism on accounting decisions is a more recent research stream started by Olsen et al. (2014), who show that more narcissistic CEOs prefer real earnings management over accrual-based earnings management. We extend this line of research by examining the impact of CEO narcissism on tone of earnings announcements.

In terms of textual analysis, our paper is most similar to Davis et al. (2015), who find CEO's dispositional optimism influences positively the tone of conference calls. Our contribution is to focus on CEO narcissism levels and to measure its impact on the tone of earnings announcements. Narcissism is a more complex psychological construct than dispositional optimism, and our measure captures different behaviors than optimism such as those related with demands for grandiosity, exploitativeness and entitlement. In sum, our study adds to the increasing growing literature on narcissism and corporate disclosure by identifying a new distinct personality trait that affects the tone of corporate disclosures even after controlling for dispositional optimism. 


\section{Literature Review and Hypotheses Development}

\subsection{Narcissism and Tone of Earnings Announcements}

Numerous studies have long documented that positive tone of financial disclosure leads to positive stock market reaction (e.g. Henry 2008; Davis et al. 2012; Price et al. 2012); this reaction is both statistically and economically significant but only lasts in the short-term, and reverses itself in the long-term (Huang et al. 2014). More recently, the literature on tone has shifted its focus toward determinants of tone. While tone is indisputably related to corporate financial performance indicators such as loss and risk (Schleicher and Walker 2010; Clatworthy and Jones 2003), prior research also find that the tone of financial disclosures is likely to depend on the capabilities, motivations, and preferences of CEOs, consistent with the Upper Echelon theory (e.g., Hambrick and Mason 1984). For instance, tone of earnings announcements is positively biased by CEO's equity-based compensation (Arslan-Ayaydin et al. 2016); tone of conference calls is positively related with manager-specific optimism (Davis et al. 2015); and tone of earnings announcements is positively affected by managerial ability (Luo and Zhou 2017). Along this line of research, this study posits that the motivation and behavioral patterns associated with CEO narcissism are likely to lead to inflated tone of earnings announcements.

The term narcissism refers to a psychological construct involving personality traits such as a grandiose sense of self-importance and uniqueness, a preoccupation with fantasies of unlimited success or power, beliefs of being special, a demand for excessive admiration, a sense of entitlement, interpersonal exploitative behavior, arrogance, lack of empathy, and envy to others (Emmons 1987; Brown et al. 2009). Consistent with social psychology research, for the purposes of this work we see narcissism not as a dichotomous psychological construct but as a continuous personality dimension (e.g., Emmons 1987; Chatterjee and Hambrick 2007) in which individuals may present different levels of narcissism without 
being diagnosed as mentally ill (Young et al. 2016). In fact, to a greater or lesser extent, all humans present some signs of narcissistic behavior (e.g., Amenic and Craig 2010) ${ }^{1}$.

Business literature has assessed the impacts of narcissism on firm decisions and business outcomes. Specifically, firms with more narcissistic CEOs are likely to employ bolder strategies (Chaterjee and Hambrick 2007), more prone to risk-taking under social praise (Chaterjee and Hambrick 2011), more likely to adopt discontinuous technologies (Gerstner et al. 2013), more likely to reduce employees' motivation to behave entrepreneurially (Engelen et al. 2016), and more likely to report their corporate social responsibility practices (Petrenko et al. 2016). Studies in accounting have documented that narcissistic CEOs prefer real earnings management over accrual-based earnings management (Olsen et al. 2014), engage more in corporate tax sheltering (Olsen and Stekelberg 2016), and are more likely to be disciplined by mandatory range estimates (Majors 2016).

Expanding the above studies, this paper proposes that more narcissistic CEOs tend to describe the performance of their companies in earnings announcements more positively. More narcissistic individuals tend to show a greater need for self-enhancement (e.g., Campbell et al. 2000). In line with this notion, this kind of individuals usually have a highly positive self-view (e.g., Horvath and Morf 2010), have more selfaggrandizing attributions (e.g., Rhodewalt and Morf 1995, 1998), an inflated view of their intelligence and attractiveness (Gabriel et al. 1994), and a more positive self-evaluation of their performance (John and Robins 1994; Farwell and Wohlwend-Lloyd 1998). Based on these notions, we propose that more narcissistic CEOs are more likely to have an exaggerated positive view of the performance of the

\footnotetext{
${ }^{1}$ It is important to note that narcissism differs from dispositional optimism in a number of ways. First, while an optimistic person has a general expectancy that good, as opposed to bad, outcomes will occur across important life domains (e.g., Scheirer and Carver 1993), narcissistic individuals use a positive approach only to reinforce their own grandiosity (e.g., Gabriel et al. 1994; John and Robins 1994). Second, narcissism describes a larger set of characteristics such as the crave for attention and recognition, exploitative behavior, arrogance, or lack of empathy, which are traits that optimistic individuals do not necessarily show (Hickman et al. 1996; Campbell et al. 2004). These differences between optimism and narcissism can result in different paths to earnings announcements. For example, in hard financial times, an optimistic CEO might have a more objective assessment about the future than a narcissist and be realistic about the impending adjustments that firms face in periods of austerity. On the other hand, a narcissistic CEO might remain irrationally and intentionally 'exuberant' or positive, which could have detrimental impacts on the firms' reputation and the well-being of stakeholders (e.g., Blickle et al. 2006; Campbell and Siedor 2016).
} 
organizations they lead and therefore, we expect them to use a more positive narrative when describing firm performance on firms' earnings announcements.

Earnings announcements are a good outlet for investigating this proposition for the following three reasons. Firstly, earnings announcements are quarterly, and provide CEOs with a continual opportunity to reinforce their grandiose image (Amenic and Craig 2010). Secondly, earnings announcements are press releases, which have fewer regulations concerning content or format relative to other SEC filings such as 10-Qs and 10-Ks, and therefore CEOs have more leeway in choice of languages. Lastly, it is important to understand the textual tone of earnings announcements because the market reaction to their contents is larger than to SEC filings such as 10-Qs (Stice 1991). We formalize the above with the following hypothesis:

H1: CEO narcissism has a positive effect on the tone of earnings announcements.

\subsection{Narcissism, Age and Tone of Earnings Announcements}

We propose that the effect of narcissism on CEOs' tone preferences is likely to be moderated by CEOs' age. Specifically, we claim that the effect of CEOs' narcissism on the tone of earnings announcements is likely to be smaller when CEOs are older. We base this proposition on recent social psychology research suggesting that older individuals could develop some personality features such as conscientiousness and humility-modesty (e.g., Ashton and Lee 2016) that can moderate (i.e., reduce) the effect of narcissism on CEO's behavior. Conscientious individuals have a higher propensity to be selfcontrolled, are more responsible to others, are hardworking, orderly, and tend to follow the rules (e.g., Roberts et al. 2009; Roberts et al. 2014). In the same vein, they tend to show a more effective behavioral self-regulation, are likely to be able to excel better in controlling their thoughts, feelings, and behaviors to act in goal-directed ways (e.g., Hoyle 2010). Likewise, humbler individuals tend to evaluate themselves and others in perspective, acknowledge their mistakes and look for feedback and advice to correct mistakes (Zhang et al. 2017). Therefore, both conscientiousness and humility are likely to be personality traits that 
could potentially reduce the positive bias in the tone of the earnings announcements produced by CEOs' narcissism. For a given level of narcissism, an older CEO (i.e., more conscientious) should be more able to realize the task he is performing (i.e., provide a neutral description of the firm's performance) and control the impulse to use a more positive tone than a younger CEO. In the same vein, an older CEO (i.e., humbler) is likely to have a more centered view of herself and this may reduce, at least partially, the positive effect of narcissism on the tone of the narratives of earnings announcements. Although it may seem paradoxical that narcissism can coexist with some a-priori contrary personality traits such as conscientiousness and humility, prior research documents that contradictory personality traits do not only coexist but their interaction has implications for important organizational outcomes (e.g., Zhang et al. 2017; Owens et al. 2015).

With these notions in mind, we propose that the effect of narcissism on managers' behavior will tend to be lower in older managers than on their younger peers. We formalize this notion with the following hypothesis:

H2: The positive effect of CEO narcissism on tone of earnings announcements is lower in firms led by an older CEO.

\section{Methodology}

\subsection{Sample Selection}

We test our hypotheses in a sample consisting of CEOs of select Fortune 500 companies over the past two decades. We choose Fortune 500 companies as these are the largest companies by revenue, and hence provide opportunities for narcissistic individuals "to gain self-affirmation and attention" (Olsen et al. 2014). Our measurement of narcissism is constructed based on the methodology of Olsen et al. (2014). To compile our sample, we first identify the 471 public companies listed in the 2015 Fortune 500 list. Second, we narrow our sample to firms with complete (non-missing) data regarding the tone of earnings

announcements from the WRDS SEC Analytics Suite, financial data from Compustat, executive 
compensation data from ExecuComp, analysts forecast data from $\mathrm{I} / \mathrm{B} / \mathrm{E} / \mathrm{S}$, and monthly stock return data from CRSP.

Consistent with Jegadeesh and $\mathrm{Wu}$ (2013), we also exclude financial firms (2-digit SIC codes 6067) as the terminology of the CEOs may have multiple interpretations; words such as 'risk' could be seen in a positive light in these firms but seen more negatively outside of the financial sector and thus these firms could cloudy the characterization of CEO positivity and negativity. We further restrict our sample to include only firms with a long-lived CEO, defined as one with a tenure lasting for at least four years. This requirement allows the calculation of CEO narcissism using information from CEO's second and third year of tenure ${ }^{2}$. Following previous psychology literature, we assume CEO narcissism is constant ${ }^{3}$ from year four of CEO tenure to the end of the analyses period. This methodology has the advantage of removing any potential reverse causality between narcissism and tone; specifically, the measure of narcissism corresponds with a period preceding the measurement of the other variables in the models (Chatterjee and Hambrick 2007; Olsen et al. 2014) and can be seen as a lagged value in the empirical specification. In other words, the sample CEOs' narcissism is not driven by current financial outcomes; thereby excluding the possibility of positive financial outcomes leading to higher levels of narcissism. We believe that this specification as well as the relative stability in CEO personality characteristics are two ways to address concerns regarding endogeneity. Finally, we require that a sample firm has annual reports corresponding to the second and third year of CEO tenure in digital form either on Mergent Online or on the company's website. Our final

\footnotetext{
${ }^{2}$ When estimating CEO narcissism, we follow Chatterjee and Hambrick (2007) and Olsen et al. (2014), who recommend that the first year of CEO tenure should be omitted when estimating CEOs' narcissism because this initial period is often non-representative (in terms of CEO behavior) and volatile because of anomalies associated with CEO succession, such as Big Baths

${ }^{3}$ Prior research considers narcissism as a stable personality trait after young adulthood (e.g., Foster et al. 2003). Even though some past work has found differences in narcissisms levels (as measured by the NPI) across different age brackets (e.g., Foster et al. 2003), this finding might not be because narcissism changes with age after young adulthood, but due to a birth cohort effect (i.e., older people belong to less narcissistic generations) (e.g. Twenge et al. 2008). In our sample, more than $95 \%$ of the CEOs are between 46 and 67 years old. Thus, for the purposes of this study, and following previous research on the effects of narcissism on firm outcomes, we conceptualize narcissism as a trait that remains unchanged across the time-periods of our sample. Consistent with this vision, other works have used a measure of narcissism that is constant over time (e.g., Olsen et al. 2014; Chatterjee and Hambrick 2007).
} 
dataset includes 280 CEOs in 215 unique firms with a total of 3,377 firm-CEO-quarter observations ranging from 1996Q2 to 2014Q1. All the variables used in the regressions are winsorized at 1 percent and 99 percent. Table 1 describes the sample selection procedure.

Table 1 Sample Selection

\begin{tabular}{lcccc} 
& & Firms & & $\begin{array}{c}\text { Firm-CEO-quarter } \\
\text { observations }\end{array}$ \\
Public Fortune 500 companies in 2015 & 471 & & \\
Non-missing data from Compustat and SEC Analytics Suite & & 373 & 8,733 \\
Merged with ExecuComp data & 320 & 8,299 \\
Remove financial sector & 280 & 7,300 \\
Merged with I/B/E/S & 273 & 6,879 \\
Merged with CRSP & & 237 & 5,747 \\
Available Narcissim measure & 215 & 3,377 \\
\hline
\end{tabular}

\subsection{Measurement of Narcissism}

Our key determinant of interest is narcissism, which is constructed along the lines of past research in business. While the psychology field commonly uses a validated measure of narcissism known as Narcissistic Personality Inventory (NPI) (e.g., Raskin and Terry 1988), this direct measure is infrequently used in archival business research due to data limitations. Top executives are usually reluctant to provide this information due to the sensitive nature of its content and the time involved in completing such a personality assessment (e.g., Chatterjee and Hambrick 2007). To address this problem, business researchers have developed their own proxies of narcissism based on observable outcomes. Chatterjee and Hambrick (2007) were pioneers ${ }^{4}$, who developed a narcissism scale calculated on the basis of five items related with

\footnotetext{
${ }^{4}$ There are other proxies for narcissism. For instance, Petrenko et al. (2016) compute a narcissism score based on CEOs' observed behavior (i.e., videos) during public presentations.
} 
observable CEO narcissistic tendencies ${ }^{5}$. Following the same idea, Olsen et al. (2014) developed a reduced version of this scale considering only three items: a) prominence of CEO photographs in annual reports, b) relative cash payment between CEO and the highest paid non-CEO executive, and c) relative non-cash payment between $\mathrm{CEO}$ and the highest paid non-CEO executive. This paper uses the 3 -item scale proposed and used by Olsen et al. $(2014)^{6}$.

The data on relative cash and non-cash payment is retrieved from ExecuComp, and the data on prominence of CEO photograph is hand collected from firm annual reports available either on Mergent Online or firm websites. We compute relative cash and non-cash payment in both year two and year three of a CEO's tenure. Relative cash payment is calculated as the ratio between total cash payment (salary and bonus) of CEO and that of the highest paid non-CEO executive. Non-cash payment is the ratio between non-cash payment (TDC1 in ExecuComp minus total cash payment) of CEO and that of the highest paid non-CEO executive. We then use the average of year two and year three cash (non-cash) pay as our final measure of relative cash (non-cash) pay. To measure the prominence of CEO photographs in annual reports, we assign a score of 1 through 5 to each CEO photograph using the following rating system:

(1) No photograph of the CEO;

(2) The CEO appears in the photograph with other executives;

(3) The CEO appears in the photograph with the Chairman of the Board;

(4) The CEO appears alone in the photograph and the photograph occupies up to half of the page; and

(5) The CEO appears alone in the photograph and the photograph occupies more than half of the page.

\footnotetext{
${ }^{5}$ The five items are: prominence of CEO photograph in annual reports, prominence of CEOs in press releases, use of first person singular pronouns in interviews, difference in cash payment between $\mathrm{CEO}$ and the highest paid non-CEO executive, and difference in non-cash payment between $\mathrm{CEO}$ and the highest paid non-CEO executive.

${ }^{6}$ This measure is also used in Olsen and Stekelberg (2016).
} 
This classification is similar, but not identical, to the ones used in Olsen et al. (2014). Our rating system distinguishes CEOs appearing in the photograph with other executives and those with the Chairman of the Board. We posit that those CEOs appearing with the chairman of the board are more likely to feel special, to have a sense of entitlement, to act superior, and to demand more attention and higher status, than those appearing with their subordinate executives. Panel B of Table 2 shows the breakdown of the CEO photo scores.

As panel A of Table 2 illustrates, the prominence of CEO photograph ranges from 1 through 5, with a mean of 3.16 and a standard deviation of 1.12 . On average, CEO cash pay is 77 percent more than that of the highest paid non-CEO executive, while CEO non-cash pay is 2.46 times of that of the highest paid non-CEO executive. This latter finding is not surprising as CEOs are more likely to be compensated in alternative means of payment such as stocks and stock options, while cash compensation often receives scrutiny in the media and popular press. In our sample of CEOs, the relative cash pay and relative non-cash pay have a correlation of 0.43 , and the prominence of CEO photograph has a correlation of $0.26(0.18)$ with cash (non-cash) pay. All the correlations are significant at 1 percent level, indicating that these three items are measuring a common construct. Following the methodology of Olsen et al. (2014) and Olsen and Stekelberg (2016), this study conducts a factor analysis using these three items. The results indicate that the three items load in a single factor (eigenvalue $>1.0$ ), which corroborates with the notion that the three components are capturing the same construct $^{7}$. We use the principal component extraction method to calculate a narcissism score Narcissism to test our hypotheses.

${ }^{7}$ Factor loadings are 0.40 for photo size, 0.55 for relative cash-pay, and 0.81 for relative non-cash pay. 
Table 2 CEO Narcissism Measure

Panel A: Descriptive Statistics \& Correlations

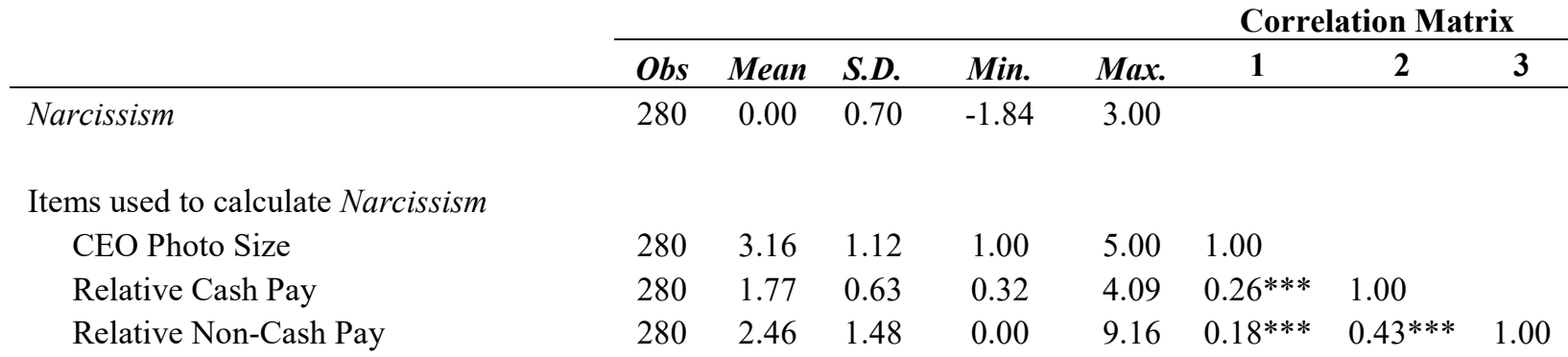

\section{Panel B: Breakdown of CEO Photo Size}

\begin{tabular}{|c|c|c|c|}
\hline Photo Size & Freq. & $\begin{array}{l}\text { Percent } \\
\text { of CEOs }\end{array}$ & $\begin{array}{c}\text { Accumulated } \\
\text { Percentage }\end{array}$ \\
\hline 1 & 32 & 11.43 & 11.43 \\
\hline 1.5 & 4 & 1.43 & 12.86 \\
\hline 2 & 34 & 12.14 & 25.00 \\
\hline 2.5 & 18 & 6.43 & 31.43 \\
\hline 3 & 44 & 15.71 & 47.14 \\
\hline 3.5 & 15 & 5.36 & 52.50 \\
\hline 4 & 107 & 38.21 & 90.71 \\
\hline 4.5 & 18 & 6.43 & 97.14 \\
\hline 5 & 8 & 2.86 & 100.00 \\
\hline Total & 280 & 100 & \\
\hline
\end{tabular}

Notes. Table 2 shows a summary of statistics for the narcissism measure (Narcissism) used in this study. Panel A shows mean (Mean), standard deviation (S.D.), minimum (Min), and maximum (Max) for Narcissism as well as for the items used to calculate this variable. Narcissism is a composite measure of CEO narcissism resulting from a factor analysis using the CEO Photo Size, Relative Cash Pay and Relative Non-Cash Pay. CEO Photo measures the prominence of CEO picture in the annual report according to the following scale: (1) No photograph of the CEO; (2) The CEO appears in the photograph with other executives; (3) The CEO appears in the photograph with the Chairman of the Board; (4) The CEO appears alone in the photograph and the photograph occupies up to half of a page; (5) The CEO appears alone in the photograph and the photograph occupies more than half of a page. Relative Cash Pay is the ratio of CEO's cash compensation to the second-highest paid executive in the firm. Relative NonCash Pay is the ratio of CEO's non-cash compensation to the second-highest paid executive in the firm. The correlation matrix among CEO Photo Size, Relative Cash Pay and Relative Non-Cash Pay is shown to the right of the summary of statistics. Panel b shows the breakdown and frequencies of CEO Photo Size.

*** Correlation significant at the 0.01 level (two-tailed).

Our final sample does not contain any CEOs working at two different companies, similar to Olsen and Stekelberg (2016). However, it does contain 64 companies that employed two different CEOs during the sample period. For these 64 cases, the spearman correlation between the narcissism scores of the former and latter CEOs is 0.03 , comparable to -0.46 in Chatterjee and Hambrick (2007) and 0.25 in Olsen et al. 
(2014). The small correlation suggests that there is little predictability between the personality of one CEO and another within a firm and thus our narcissism score is unlikely to be driven by any firm-level characteristics.

\subsection{Effect of CEO Narcissism on Tone}

To test our main hypothesis, we aim to learn how the CEO's personality might be influencing the tone of earnings announcements. To measure the tone of earnings announcements $\left(\right.$ Tone $_{\text {ift }}$ ) for manager $\mathrm{i}$ at firm $\mathrm{f}$, at time $\mathrm{t}$, we follow prior studies in calculating the difference between the number of positive words and negative words, multiplied by 100 , and divided by the total number of words in each earnings announcement over the sample period (Feldman et al. 2010; Davis and Tama-Sweet 2012; Twedt and Rees 2012; Davis et al. 2015; Arslan-Ayaydin et al. 2016). The numbers of positive and negative words are retrieved from WRDS SEC Analytics Suite using the methodology developed in Loughran and McDonald (2011). Specifically, Loughran and McDonald (2011) develop a dictionary of words commonly used in financial statements, identify the sentiment they carry, and calculate the tone of $10-$ Ks based on word counts as well as the positivity and negativity of each word. A number of highly cited studies have since used this methodology to measure tone of financial texts, and for consistency and reliability we follow the literature for this key variable in our study (e.g., Twedt and Rees 2012; Jegadeesh and Wu 2013; Liu and McConnell 2013; Loughran and McDonald 2014). Using Tone as the dependent variable, we estimate the following Ordinary Least Squares regression model:

$$
\text { Tone }_{\text {ift }}=\beta_{0}+\beta_{1} \text { Narcissism }_{i}+\beta_{2} X_{i f t}+\beta_{3} Y_{\text {ift }}+\text { Ind }_{f}+\text { Year }_{t}+Q t r_{t}+\varepsilon_{i f t}
$$

where $\operatorname{Narcissism}_{i}$ is the estimated narcissism of CEO $i$ (which remains constant along the timespan of the study), $X_{i f t}$ is a vector of firm-level controls, $Y_{i f t}$ is a vector of manager-level controls, and $\operatorname{Ind}_{f}$, Year $_{t}$, and $Q t r_{t}$ account for industry, year and quarter fixed effects, respectively. The coefficient of primary interest is $\beta_{1}$, which should be positive and statistically significant if the CEO's narcissism affects the tone, consistent with hypothesis 1 . The positive coefficient on Narcissism $_{i}$ would imply that more 
narcissistic CEOs issue more positive earnings announcements than less narcissistic CEOs, controlling for other determinants of tone.

Consistent with prior studies, we include a number of control variables at the firm and managerlevel in the regression model in order to rule out and account for other possible explanations for our results. At the firm level, past research on tone has controlled for firm size as larger firms are likely to have a more conservative (negative) tone (e.g., Jegadeesh and Wu 2013; Huang et al. 2014). We calculate firm size as logarithm of quarterly total assets ${ }^{8}$ and expect Size to be negatively related with Tone. In terms of firm performance, it has been argued that whether or not a firm meets or beats analysts forecast affects its earnings announcement tone (Davis et al. 2015; Arslan-Ayaydin et al. 2016). We therefore include Surp as a control variable. Earnings surprise (Surp) is calculated as the difference between actual quarterly Earnings Per Share (EPS) and the average analyst forecast of EPS.

We further include four variables as controls for performance: EPS, ROA, Loss, and LeadROA. Firms with more narcissistic CEOs have higher earnings per share (Olsen et al. 2014), which may in turn positively affect tone. Return on assets $(R O A)$ has been shown to be positively related with tone of earnings announcements (e.g., Feldman et al. 2010; Davis and Tama-Sweet 2012). This paper calculates $R O A$ as quarterly earnings before extraordinary items divided by quarter-end total assets. Consistent with a number of studies on tone (e.g., Davis and Tama-Sweet 2012; Huang et al. 2014), we also control for an indicator variable of quarterly loss Loss, which takes the value of 1 if $R O A$ is negative, and 0 otherwise. Further, following Davis et al. (2015), this paper also controls for LeadROA as earnings announcements tone may contain management inside information on future performance (Li 2010; Huang et al. 2014).

Market-to-book ratio $(M T B)$, a proxy for firm growth, is another common control variable as higher-growth firms are likely to have a more positive tone than their lower-growth peers (e.g., Huang et al. 2014; Arslan-Ayaydin et al. 2016). The market value is calculated as the sum of quarter-end market

\footnotetext{
${ }^{8}$ We obtain similar results using company's market capitalization and revenue as proxies for size.
} 
capitalization and long-term debt; and the book value as quarter-end total assets. Consistent with ArslanAyaydin et al. (2016), this paper controls for the number of analysts following the firm (Nanalyst), as analyst attention may provide management incentives for a conservative (negative) tone. In order to further capture the forward-looking characteristic of tone, we also include Risk, which is measured as the standard deviation of monthly stock returns over the past twelve months (Huang et al. 2014).

We control for differences between managers by examining two key explanations identified in the literature. The first is the managerial equity-based incentives. Arslan-Ayaydin et al. (2016) show that CEOs with significant equity-based compensation and therefore higher equity-based incentives are more likely to issue positive earnings announcements. We approximate managerial equity-based incentives with the variable Wealth, which is defined as the logarithm of the sum of three components: (1) aggregate value of shares owned by the CEO, (2) aggregate value of unexercisable options, and (3) aggregate value of unexercised exercisable options to control for CEO equity position in the firm.

The second manager level explanation concerns the optimism level of the CEO. It is possible the tone of corporate disclosures is influenced by manager specific optimism -- more optimistic CEOs use more positive language when describing the firm's results. To measure manager specific dispositional optimism, we use two variables identified in the literature -- Gender and Recession. Specifically, prior studies have documented that male and female managers and directors have different risk preferences (e.g. Adams and Funk 2012; Berger et al. 2014; Francis et al. 2015), and gender has also been identified as a potential proxy for managerial optimism by previous work (e.g. Davis et al. 2015). We therefore include Gender in the model, which equals 1 if the CEO is female, and 0 if male. Further, Schoar and Zuo (2016) show that managers who begin their careers during recessions tend to be more conservative; we therefore include Recession as a control variable for earnings announcements tone. Recession equals 1 if there is a recession when the CEO is 22 years old, at which Schoar and Zuo (2016) assume a CEO begins her career; and 0 otherwise. 
Both of the above variables are designed to capture the overall dispositional optimism of the CEO. However, it is also possible that the economic conditions make the manager temporarily more positive about the future perspective of the company, which may impact the tone of the earnings announcements. We therefore introduce an additional control, Confidence, which measures the overall confidence of CEOs at time t. Confidence is an indicator variable equal to 1 if the CEO Confidence Index compiled by The Conference Board is equal to or larger than 50 (which indicates that CEOs are bullish on the current state of the economy) ${ }^{9}$, and zero otherwise. The variable is an aggregate variable based on survey responses by approximately $100 \mathrm{CEOs}$ and is therefore not a manager-level variable per se. In other words, it does not vary across CEOs but instead varies across time and is designed to capture overall temporal differences in optimism among CEOs based on perceived market conditions.

Lastly, we control for industry, year, and quarter fixed effects to address the concern that tone is specific to industry and macro economy. Industry and time fixed effects further allow our model to control for the temporal managerial optimism resulting from the general state of the economy as well as the circumstances or perspectives specific to each of the industries in our sample.

\subsection{Moderation Effect of Age}

To investigate the moderation effect of age, we augment Equation (1) with the age of the CEO and an interaction term between Narcissism and Age. Specifically, we estimate the following regression using Ordinary Least Squares:

$$
\begin{aligned}
\text { Tone }_{i f t}=\beta_{0}+ & \beta_{1} \text { Narcissism }_{i}+\beta_{2} \text { Age }_{i f t}+\beta_{3} \text { Narcissism }_{i} * \text { Age }_{i f t}+\beta_{4} X_{i f t}+\beta_{5} Y_{i f t}+\text { Ind }_{f} \\
& + \text { Year }_{t}+Q t r_{t}+\varepsilon_{i f t}
\end{aligned}
$$

\footnotetext{
${ }^{9}$ The Conference Board, a non-profit business membership and research association, conducts a CEO Confidence Survey to approximately 100 CEOs in various industries on their perceptions to the economic outlook, and publishes Measure of CEO Confidence, which is a number that ranges from 0 to 100, with 0 representing substantially worse state of economy and 100 representing substantially better state of economy.
} 
where $A g e_{\text {ift }}$ is the age in years of CEO $i$, for firm $f$, at time $t$. The coefficient of primary interest is $\beta_{3}$, which should be significantly negative if the CEO's personality effect on the tone diminishes with age, consistent with hypothesis 2 .

\section{Empirical Results}

\subsection{Descriptive Statistics and Correlations}

We report descriptive statistics of all the variables in Table 3 . The mean value of Tone is 0.18 , and the median value is 0.33 , suggesting that in general, earnings announcements carry a positive sentiment (Davis and Tama-Sweet 2012). An average CEO in our sample is 57 years old, with the youngest CEO being 44 years old, and the oldest 72 . Out of 280 CEOs in the sample, six of them (roughly $2 \%$ ) are female; this percentage is comparable to those documented in prior studies (Kahn and Vieito 2013; Ho et al. 2015; $\mathrm{Ng}$ and Sears 2017). The smallest firm in our sample has total assets of $\$ 1.44$ billion; the largest has total assets of $\$ 344$ billion, while an average firm has total assets of $\$ 13$ billion. On average, the firms in the sample report earnings surprise of $\$ 0.03$ and EPS of $\$ 0.68$. Both ROA and LeadROA have mean values of 0.04 , and median values of 0.03 . Only $7 \%$ of the observations have a negative $R O A$. Meanwhile, $M T B$ has a mean of 0.88 and a median of 0.70 , which are both much smaller than those reported in other studies of financial disclosure tone (e.g., Rogers et al. 2011; Davis and Tama-Sweet 2012; Huang et al. 2014). This is because the sample firms used in this study are the largest firms in revenue and hence have lower growth. On average, the number of analysts tracking each firm ranges from 4 to 45 with an average of 17.66 analysts for each firm-quarter. Lastly, average volatility of monthly stock returns is 0.09 , comparable to that reported in Huang et al. (2014). 
Table 3 Summary of statistics

\begin{tabular}{lcrrrrrrr}
\hline Variable & $\mathbf{n}$ & Mean & S.D & Min & $\mathbf{0 . 2 5}$ & Mdn & $\mathbf{0 . 7 5}$ & Max \\
\hline Tone & 3,377 & 0.18 & 0.41 & -1.54 & 0 & 0.33 & 0.41 & 1.13 \\
Narcissism & 3,377 & 0.06 & 0.76 & -1.23 & 0.48 & -0.01 & 0.42 & 2.77 \\
Age & 3,377 & 57.13 & 5.30 & 44 & 54 & 58 & 61 & 72 \\
Wealth & 3,377 & 10.42 & 1.56 & 0 & 9.73 & 10.46 & 11.19 & 16.17 \\
Gender & 3,377 & 0.02 & 0.13 & 0 & 0 & 0 & 0 & 1 \\
Recession & 3,377 & 0.10 & 0.30 & 0 & 0 & 0 & 0 & 1 \\
Confidence & 3,377 & 0.59 & 0.49 & 0 & 0 & 1 & 1 & 1 \\
Size & 3,377 & 9.49 & 1.14 & 7.26 & 8.63 & 9.55 & 10.24 & 12.75 \\
Surp & 3,377 & 0.03 & 0.12 & -0.46 & 0 & 0.02 & 0.06 & 0.52 \\
EPS & 3,377 & 0.68 & 0.61 & -1.19 & 0.32 & 0.57 & 0.92 & 2.9 \\
ROA & 3,377 & 0.04 & 0.04 & -0.08 & 0.01 & 0.03 & 0.06 & 0.15 \\
Loss & 3,377 & 0.07 & 0.25 & 0 & 0 & 0 & 0 & 1 \\
LeadROA & 3,377 & 0.04 & 0.04 & -0.08 & 0.01 & 0.03 & 0.06 & 0.15 \\
MTB & 3,377 & 0.88 & 0.58 & 0.22 & 0.53 & 0.7 & 1 & 3.72 \\
Nanalyst & 3,377 & 17.66 & 8.02 & 4 & 12 & 16 & 22 & 45 \\
Risk & 3,377 & 0.09 & 0.05 & 0.03 & 0.05 & 0.07 & 0.10 & 0.29 \\
\hline
\end{tabular}

Notes. Table 3 shows mean (Mean), standard deviation (S.D.), minimum (Min), 25 percentile (25\%), median (Mdn), 75 percentile (75\%) and maximum (Max) of the variables used in this study. Tone accounts for the tone of quarterly earnings announcement and it is defined as $100 *$ (positive word count - negative word count) divided by the total word count of the quarterly earnings announcement. Narcissism is a composite measure of CEO narcissism resulting from a factor analysis using the CEO photo size, relative cash pay and relative non-cash pay. Age is CEO age in years. Wealth is the natural logarithm of the aggregate dollar amount of CEO's firm-specific equity-based wealth (i.e., total value of shares owned by the CEO, value of unexercisable options, and value of unexercised exercisable options). Gender equals 1 if the CEO is female, and 0 if male. Recession equals 1 if there is a recession when the CEO is 22 years old and, 0 otherwise. Confidence equals 1 if the CEO Confidence Index is equal or larger than 50, and zero otherwise. Size is the natural logarithm of quarterly total assets. Surp is the difference between actual quarterly earnings per share (EPS) and the average analyst forecast of EPS. EPS is the actual quarterly earnings per share; $R O A$ is the quarterly income before extraordinary items divided by the quarter-end total assets. Loss equals 1 if ROA is negative, and 0 otherwise. LeadROA is ROA in the following quarter. MTB is the quarter-end market capitalization plus quarter-end long-term debt divided by quarter-end total assets. Nanalyst is the number of analyst following in the current quarter. Risk is the standard deviation of monthly stock return for the past twelve months.

Table 4 reports the Pearson correlations among the variables. This table sheds light on simple associations between our variables of interest and our key dependent variable (Tone) in addition to providing some insight into potential multicollinearity. In particular, among the control variables, Surp, $E P S, R O A$, and LeadROA are positively and significantly correlated with Tone, and Loss is negatively and significantly correlated with Tone, implying that higher performance and higher earnings surprise are likely to increase tone of earnings announcements. In addition, Recession is negatively and statistically significantly associated with Tone, consistent with the findings of Schoar and Zuo (2016). 
As to relationships among the independent variables, Age, Size, MBE, Surp, EPS, ROA, LeadROA, and Wealth are all positively and significantly correlated with Narcissism. These suggest that larger firms are likely to hire more narcissistic managers, and that this kinds of managers are more likely to outperform their peers and receive higher compensation (Chatterjee and Hambrick 2007; Olsen et al. 2014). Gender, MTB and Risk are negatively correlated with Narcissism, indicating that male CEOs are likely to be more narcissistic, more narcissistic CEOs are more likely to work in higher-growth firms, and firms employing more narcissistic CEOs are likely to have smaller stock return volatilities. Age is negatively and significantly correlated with Gender, Recession, ROA, LeadROA, MTB, and Nanalyst. These demonstrate that older CEOs in our sample are more likely to be men, more likely to begin their careers in a recession year, more likely to report lower earnings, more likely to work in lower-growth firms, and are followed by fewer analysts. Nanalyst is positively correlated with Size, EPS, ROA, LeadROA, MTB, and Wealth, suggesting that larger firms, higher-performance firms, higher-growth firms, and firms with highercompensated CEOs are more likely to attract analyst attention. 
Table 4 Correlation Matrix

Panel A. Correlation Variables TONE to SURP

\begin{tabular}{|c|c|c|c|c|c|c|c|c|}
\hline & Tone & Narcissism & Age & Confidence & Gender & Recession & Size & Surp \\
\hline Tone & 1 & & & & & & & \\
\hline Narcissism & -0.016 & 1 & & & & & & \\
\hline Age & -0.007 & $0.121 * * *$ & 1 & & & & & \\
\hline Wealth & $0.033^{*}$ & $0.063 * * *$ & $0.087 * * *$ & 1 & & & & \\
\hline Gender & 0.014 & $-0.041 * *$ & $-0.085 * * *$ & $-0.032 *$ & 1 & & & \\
\hline Recession & $-0.067 * * *$ & -0.008 & $-0.141 * * *$ & $-0.049 * * *$ & $0.067 * * *$ & 1 & & \\
\hline Confidence & $-0.067 * * *$ & -0.024 & 0.009 & $0.039 * *$ & 0.014 & 0.02 & 1 & \\
\hline Size & $-0.05 * * *$ & $0.202 * * *$ & $0.144 * * *$ & $0.159 * * *$ & 0.017 & $-0.037 * *$ & $-0.051 * * *$ & 1 \\
\hline Surp & $0.046^{* * *}$ & $0.057 * * *$ & $0.042 * *$ & $0.06^{* * *}$ & $-0.029 *$ & -0.012 & $0.05 * * *$ & -0.001 \\
\hline$E P S$ & $0.117 * * *$ & $0.195 * * *$ & $0.11 * * *$ & $0.261 * * *$ & -0.015 & $-0.033^{*}$ & $-0.093 * * *$ & $0.283 * * *$ \\
\hline$R O A$ & $0.037 * *$ & $0.089 * * *$ & $-0.046^{* * *}$ & $0.218 * * *$ & $0.073 * * *$ & $0.035^{* *}$ & $-0.126^{* * *}$ & 0.016 \\
\hline Loss & $-0.076 * * *$ & $-0.039 * *$ & $0.031 *$ & $-0.192 * * *$ & $-0.036^{* *}$ & 0.025 & $0.036^{* * *}$ & $-0.078 * * *$ \\
\hline LeadROA & $0.051^{* * *}$ & $0.086 * * *$ & $-0.044^{* *}$ & $0.242 * * *$ & $0.078 * * *$ & $0.031 *$ & $-0.051 * * *$ & 0.007 \\
\hline$M T B$ & 0.023 & $-0.114 * * *$ & $-0.111 * * *$ & $0.172 * * *$ & 0.006 & $0.048 * * *$ & $-0.061 * * *$ & $-0.329 * * *$ \\
\hline Nanalyst & -0.007 & 0.019 & $-0.039 * *$ & $0.279 * * *$ & $-0.054 * * *$ & 0.018 & $-0.015^{* * *}$ & $0.255 * * *$ \\
\hline Risk & -0.019 & $-0.151^{* * *}$ & 0.024 & $-0.138^{* * *}$ & $-0.054^{* * *}$ & -0.01 & $0.149 * * *$ & $-0.253 * * *$ \\
\hline
\end{tabular}




\section{Table 4 Correlation Matrix (Continued)}

Panel B. Correlation Variables EPS to Risk

\begin{tabular}{|c|c|c|c|c|c|c|c|c|}
\hline & EPS & $\boldsymbol{R O A}$ & Loss & LeadROA & ВТМ & Wealth & Nanalyst & Risk \\
\hline \multicolumn{9}{|l|}{ Tone } \\
\hline \multicolumn{9}{|l|}{ Narcissism } \\
\hline \multicolumn{9}{|l|}{ Age } \\
\hline \multicolumn{9}{|l|}{ Gender } \\
\hline \multicolumn{9}{|l|}{ Recession } \\
\hline \multicolumn{9}{|c|}{ Confidence } \\
\hline Surp & 1 & & & & & & & \\
\hline EPS & $0.318 * * *$ & 1 & & & & & & \\
\hline$R O A$ & $0.058 * * *$ & $0.348 * * *$ & 1 & & & & & \\
\hline Loss & $-0.092 * * *$ & $-0.351 * * *$ & $-0.468 * * *$ & 1 & & & & \\
\hline LeadROA & $0.124 * * *$ & $0.336^{* * *}$ & $0.575^{* * *}$ & $-0.412 * * *$ & 1 & & & \\
\hline MTB & $0.050 * * *$ & $-0.065 * * *$ & $0.244 * * *$ & 0.025 & $0.260 * * *$ & 1 & & \\
\hline Nanalyst & 0.008 & $0.129 * * *$ & $0.279 * * *$ & $-0.077 * * *$ & $0.246^{* * *}$ & $0.375^{* * *}$ & 1 & \\
\hline Risk & $0.057 * * *$ & $-0.260 * * *$ & $-0.256^{* * *}$ & $0.317 * * *$ & $-0.264 * * *$ & $0.185^{* * *}$ & -0.012 & 1 \\
\hline
\end{tabular}

Notes. Table 4 presents Pearson correlations among the variables used in this study. Tone accounts for the tone of quarterly earnings announcement and it is defined as $100^{*}$ (positive word count - negative word count) divided by the total word count of the quarterly earnings announcement. Narcissism is a composite measure of CEO narcissism resulting from a factor analysis using the CEO photo size, relative cash pay and relative non-cash pay. Age is CEO age in years. Wealth is the natural logarithm of the aggregate dollar amount of CEO's firm-specific equity-based wealth (i.e., total value of shares owned by the CEO, value of unexercisable options, and value of unexercised exercisable options). Gender equals 1 if the CEO is female, and 0 if male. Recession equals 1 if there is a recession when the CEO is 22 years old and, 0 otherwise. Confidence equals 1 if the CEO Confidence Index is equal or larger than 50, and zero otherwise. Size is the natural logarithm of quarterly total assets. Surp is the difference between actual quarterly earnings per share (EPS) and the average analyst forecast of EPS. $E P S$ is the actual quarterly earnings per share; $R O A$ is the quarterly income before extraordinary items divided by the quarter-end total assets. Loss equals 1 if $R O A$ is negative, and 0 otherwise. LeadROA is ROA in the following quarter. MTB is the quarter-end market capitalization plus quarter-end long-term debt divided by quarter-end total assets. Nanalyst is the number of analyst following in the current quarter. Risk is the standard deviation of monthly stock return for the past twelve months.

* Significance at the $10 \%$ level; ** significance at the $5 \%$ level; *** significance at the $1 \%$ level. 


\subsection{Multivariate Results}

Table 5 reports the main empirical results. Column (1) contains the baseline model showing the effects of the control variables on tone of earnings announcements. Gender is positively associated with Tone, suggesting that firms with female CEOs are more likely to have positive tone in their earnings announcements, relative to firms with male CEOs. This implies that female CEOs are likely to be more aggressive in hyping the tone, consistent with the findings of Adams and Funk (2012). Size is negatively and significantly associated with Tone, in line with prior studies such as Li (2010), who argues that larger companies have greater scrutiny from stakeholders, and therefore, may use a more conservative tone in order to avoid potentially costly litigation. EPS is positively associated with Tone, and Loss is negatively associated and statistically significant, indicating that firms with higher (lower) performance tend to use a more positive (negative) tone (Clatworthy and Jones 2003; Schleicher and Walker 2010).

Column (2) of Table 5 augments the baseline model with our proxy for CEO narcissism (Narcissism). Narcissism is positively and significantly associated with Tone, with a coefficient of 0.025 and a t-statistic of 2.31 supporting hypothesis 1 that CEO narcissism has a positive effect on the tone of earnings announcements.

Column (3) of Table 5 also includes CEO age in the model, and shows that CEO age is negatively associated with earnings announcements tone, with a coefficient of -0.003 and a $t$-value of -1.89 . This coincides with prior studies, which suggest that older CEOs are likely to be more conservative and more risk-averse (Hambrick and Mason 1984; Prendergast and Stole 1996; Serfling 2014). Table 4 shows that Narcissism is significantly correlated with most of the control variables, including CEO age. To examine whether multicollinearity influences the results in column (3), we calculate Variance Inflation Factor (VIF). A commonly used cutoff value for indicating strong and weak multicollinearity is VIF of 10; a VIF above 10 indicates strong multicollinearity. Among all independent variables, the largest VIF is 3.55 , and Narcissism has a VIF of 1.59. We therefore conclude that multicollinearity does not play a large role in the empirical specifications that we estimate. 
Column (4) then expands the analysis with an interaction between Narcissism and Age. While Narcissism remains positive and statistically significant with a coefficient of 0.365 and a t-value of 2.92 , the coefficient on the interaction is -0.006 and is statistically significant with a t-value of -2.72 ; suggesting that impact of narcissism on CEOs' tone preferences is smaller for older CEOs.

Table 5 Effect of CEO narcissism on the tone of quarterly earnings announcements

\begin{tabular}{|c|c|c|c|c|c|}
\hline & VIF & 1 & 2 & 3 & 4 \\
\hline Narcissism & 1.59 & & $\begin{array}{c}0.025 * * \\
(2.31)\end{array}$ & $\begin{array}{c}0.026 * * \\
(2.38)\end{array}$ & $\begin{array}{c}0.365 * * * \\
(2.92)\end{array}$ \\
\hline Narcissism $x$ Age & & & & & $\begin{array}{c}-0.006 * * * \\
(-2.72)\end{array}$ \\
\hline Age & 1.50 & & & $\begin{array}{c}-0.003 * \\
(-1.89)\end{array}$ & $\begin{array}{c}-0.003 * * \\
(-2.06)\end{array}$ \\
\hline Wealth & 1.68 & $\begin{array}{l}0.002 \\
(0.29)\end{array}$ & $\begin{array}{l}0.002 \\
(0.36)\end{array}$ & $\begin{array}{l}0.003 \\
(0.55)\end{array}$ & $\begin{array}{l}0.005 \\
(0.88)\end{array}$ \\
\hline Gender & 1.39 & $\begin{array}{c}0.131 * * \\
(1.99)\end{array}$ & $\begin{array}{c}0.137 * * \\
(2.07)\end{array}$ & $\begin{array}{c}0.131 * * \\
(1.98)\end{array}$ & $\begin{array}{c}0.144 * * \\
(2.18)\end{array}$ \\
\hline Recession & 1.08 & $\begin{array}{l}-0.035 \\
(-1.56)\end{array}$ & $\begin{array}{l}-0.034 \\
(-1.49)\end{array}$ & $\begin{array}{c}-0.039 * \\
(-1.72)\end{array}$ & $\begin{array}{l}-0.042 * \\
(-1.85)\end{array}$ \\
\hline Confidence & 1.99 & $\begin{array}{l}-0.017 \\
(-0.88)\end{array}$ & $\begin{array}{l}-0.016 \\
(-0.85)\end{array}$ & $\begin{array}{l}-0.016 \\
(-0.85)\end{array}$ & $\begin{array}{l}-0.016 \\
(-0.85)\end{array}$ \\
\hline Size & 3.21 & $\begin{array}{c}-0.060 * * * \\
(-5.54)\end{array}$ & $\begin{array}{c}-0.064 * * * \\
(-5.90)\end{array}$ & $\begin{array}{c}-0.062 * * * \\
(-5.68)\end{array}$ & $\begin{array}{c}-0.059 * * * \\
(-5.46)\end{array}$ \\
\hline Surp & 1.21 & $\begin{array}{l}0.037 \\
(0.63)\end{array}$ & $\begin{array}{l}0.035 \\
(0.60)\end{array}$ & $\begin{array}{l}0.038 \\
(0.66)\end{array}$ & $\begin{array}{l}0.046 \\
(0.79)\end{array}$ \\
\hline EPS & 2.16 & $\begin{array}{c}0.058 * * * \\
(3.87)\end{array}$ & $\begin{array}{c}0.056^{* * *} \\
(3.72)\end{array}$ & $\begin{array}{c}0.055 * * * \\
(3.65)\end{array}$ & $\begin{array}{c}0.051 * * * \\
(3.38)\end{array}$ \\
\hline$R O A$ & 3.55 & $\begin{array}{l}0.229 \\
(0.57)\end{array}$ & $\begin{array}{l}0.208 \\
(0.52)\end{array}$ & $\begin{array}{l}0.223 \\
(0.56)\end{array}$ & $\begin{array}{l}0.251 \\
(0.63)\end{array}$ \\
\hline Loss & 1.73 & $\begin{array}{l}-0.068 * \\
(-1.75)\end{array}$ & $\begin{array}{l}-0.074^{*} \\
(-1.90)\end{array}$ & $\begin{array}{l}-0.072 * \\
(-1.86)\end{array}$ & $\begin{array}{l}-0.071 * \\
(-1.84)\end{array}$ \\
\hline LeadROA & 3.24 & $\begin{array}{l}0.252 \\
(0.69)\end{array}$ & $\begin{array}{l}0.233 \\
(0.64)\end{array}$ & $\begin{array}{l}0.245 \\
(0.67)\end{array}$ & $\begin{array}{l}0.267 \\
(0.73)\end{array}$ \\
\hline$B T M$ & 2.51 & $\begin{array}{l}-0.018 \\
(-1.12)\end{array}$ & $\begin{array}{l}-0.018 \\
(-1.12)\end{array}$ & $\begin{array}{l}-0.019 \\
(-1.14)\end{array}$ & $\begin{array}{l}-0.016 \\
(-0.98)\end{array}$ \\
\hline Nanalyst & 2.66 & $\begin{array}{l}0.001 \\
(0.93)\end{array}$ & $\begin{array}{l}0.001 \\
(1.05)\end{array}$ & $\begin{array}{l}0.001 \\
(0.86)\end{array}$ & $\begin{array}{l}0.001 \\
(0.48)\end{array}$ \\
\hline Risk & 2.15 & $\begin{array}{l}-0.109 \\
(-0.57)\end{array}$ & $\begin{array}{l}-0.080 \\
(-0.42)\end{array}$ & $\begin{array}{l}-0.083 \\
(-0.43)\end{array}$ & $\begin{array}{l}-0.077 \\
(-0.41)\end{array}$ \\
\hline Year Fixed Effects & & Yes & Yes & Yes & Yes \\
\hline Quarter Fixed Effects & & Yes & Yes & Yes & Yes \\
\hline Industry Fixed Effects & & Yes & Yes & Yes & Yes \\
\hline Constant & & $0.934 * * *$ & $0.905 * * *$ & $1.018 * * *$ & $0.909 * * *$ \\
\hline
\end{tabular}


Table 5 Effect of CEO narcissism on the tone of quarterly earnings announcements

\begin{tabular}{lccccc}
\hline & VIF & 1 & 2 & 3 & 4 \\
\hline & & $(2.93)$ & $(2.83)$ & $(3.11)$ & $(2.77)$ \\
Observations & & 3,377 & 3,377 & 3,377 & 3,377 \\
Adjusted R & & 0.159 & 0.160 & 0.161 & 0.163 \\
\hline
\end{tabular}

Notes. Models in Table 5 are OLS models with robust errors. The dependent variable in all models is Tone. Tone accounts for the tone of quarterly earnings announcement and it is defined as $100 *$ (positive word count - negative word count) divided by the total word count of the quarterly earnings announcement. Model 1shows the effect of the set of control variables. Wealth is the natural logarithm of the aggregate dollar amount of CEO's firm-specific equity-based wealth (i.e., total value of shares owned by the CEO, value of unexercisable options, and value of unexercised exercisable options). Gender equals 1 if the CEO is female, and 0 if male. Recession equals 1 if there is a recession when the CEO is 22 years old and, 0 otherwise. Confidence equals 1 if the CEO Confidence Index is equal or larger than 50, and zero otherwise. Size is the natural logarithm of quarterly total assets. Surp is the difference between actual quarterly earnings per share (EPS) and the average analyst forecast of EPS. EPS is the actual quarterly earnings per share; $R O A$ is the quarterly income before extraordinary items divided by the quarterend total assets. Loss equals 1 if ROA is negative, and 0 otherwise. LeadROA is ROA in the following quarter. $M T B$ is the quarter-end market capitalization plus quarter-end long-term debt divided by quarter-end total assets. Nanalyst is the number of analyst following in the current quarter. Risk is the standard deviation of monthly stock return for the past twelve months. Model 2 includes Narcissism, which is a composite measure of CEO narcissism resulting from a factor analysis using the CEO photo size, relative cash pay and relative non-cash pay. Model 3 adds Age, which is the CEO age in years. Model 4 shows the interaction between Narcissism and Age. To the right of the models is presented the Variance Inflation Factor (VIF) as a multicollinearity indicator. All models include year, quarter, and industry fixed effects. Estimators of each variable are reported on the top row, and Z-test values appear in brackets below each coefficient.

* Significance at the $10 \%$ level; ** significance at the $5 \%$ level; *** significance at the $1 \%$ level.

To better understand the dynamic relationship between narcissism and age, we estimate the impact of these two continuous variables on the tone of earnings announcements for two hypothetical CEOs. The first is designed to represent the young highly-narcissistic CEO and is evaluated at the $25^{\text {th }}$ percentile of Age and $75^{\text {th }}$ percentile of Narcissism. The predicted tone for this CEO is 0.216 . The predicted tone is evaluated at the mean for all variables except Narcissism and Age. In contrast, the older less-narcissistic CEO is evaluated at $75^{\text {th }}$ percentile of Age and $25^{\text {th }}$ percentile of Narcissism and has a predicted tone of 0.168 . The difference, $0.048(0.216-0.168)$, relative to the mean of 0.18 , suggests young highly-narcissistic managers use 26.7 percent $(0.048 / 0.18)$ more positive words than their older less-narcissistic counterparts.

\subsection{Additional Analyses on Market Reaction}

Numerous prior studies have documented a strong stock market reaction to the tone of earnings announcements. As documented above narcissistic CEO have a positive bias in the tone of their earnings announcements. In this section, we investigate whether the stock market is aware of this bias. We posit that while the stock market reacts positively to tone of earnings announcements, it discounts the reaction 
for more narcissistic CEOs. To examine these, we collect daily market return data from CRSP, and calculate three-day cumulative abnormal return (CAR) from day -1 to day $1 \mathrm{CAR}(-1,1)$, with day -1 being the day prior to earnings announcements, day 0 being the day of earnings announcements, and day 1 being the day after earnings announcements. We regress CAR(-1,1) against Tone, Narcissism, their interaction, and all control variables. The empirical results are presented in Table 6.

Table 6 Cumulative abnormal returns on the three-day window around earnings announcements

\begin{tabular}{|c|c|c|c|c|c|}
\hline & VIF & 1 & 2 & 3 & 4 \\
\hline Tone & 1.23 & $\begin{array}{c}0.0047^{*} \\
(1.71)\end{array}$ & & $\begin{array}{c}0.0049 * \\
(1.80)\end{array}$ & $\begin{array}{c}0.0060 * * \\
(2.10)\end{array}$ \\
\hline Narcissism & & & $\begin{array}{c}-0.0021 \\
(-1.20)\end{array}$ & $\begin{array}{c}-0.0023 \\
(-1.31)\end{array}$ & $\begin{array}{c}-0.0006 \\
(-0.34)\end{array}$ \\
\hline Tone $x$ Narcissism & 1.89 & & & & $\begin{array}{c}-0.0058^{*} \\
(-1.76)\end{array}$ \\
\hline Firm-level Control Variables & & Yes & Yes & Yes & Yes \\
\hline Manager-level Control Variables & & Yes & Yes & Yes & Yes \\
\hline Year Fixed Effects & & Yes & Yes & Yes & Yes \\
\hline Quarter Fixed Effects & & Yes & Yes & Yes & Yes \\
\hline Firm Fixed Effects & & Yes & Yes & Yes & Yes \\
\hline Constant & & $\begin{array}{c}0.0830 * * * \\
(3.06)\end{array}$ & $\begin{array}{c}0.0903 * * * \\
(3.25)\end{array}$ & $\begin{array}{c}0.0865 * * * \\
(3.17)\end{array}$ & $\begin{array}{c}0.0850^{* * *} \\
(2.91)\end{array}$ \\
\hline Observations & & 2,716 & 2,716 & 2,716 & 2,716 \\
\hline Adjusted $\mathrm{R}^{2}$ & & 0.062 & 0.061 & 0.062 & 0.062 \\
\hline
\end{tabular}

Notes. Models in Table 6 are OLS models with robust errors. The dependent variable in all models is $C A R(-1,1)$, which accounts for firm $i$ 's cumulative abnormal return during a 3-day time window around the earnings announcement at time t. Tone accounts for the tone of quarterly earnings announcement and it is defined as $100 *$ (Positive word count - Negative word count) divided by the total word count of the quarterly earnings announcement. Narcissism, is a composite measure of CEO narcissism resulting from a factor analysis using the CEO photo size, relative cash pay and relative non-cash pay. All models include the set of firm-level control variables (i.e., Size, Surp, EPS, ROA, Loss, LeadROA, MTB, Nanalyst and Risk), the set of manger-level control variables (i.e., Age, Wealth, Gender, Recession, Confidence and Charity) as well as year, quarter, and firm fixed effects. To the left of the models is presented the Variance Inflation Factor (VIF) as a multicollinearity indicator. Estimators of each variable are reported on the top row, and Z-test values appear in brackets below each coefficient.

$*$ Significance at the $10 \%$ level; $* *$ significance at the $5 \%$ level; *** significance at the $1 \%$ level. 
Column 1 of Table 6 demonstrates that there is a positive association between the three-day cumulative abnormal return around an earnings announcement and its tone. The coefficient is 0.0047 , comparable to prior studies documenting similar association (e.g. Davis et al. 2012; Huang et al. 2014). This coefficient is also statistically significant with a t-value of 1.71 and a one-tailed p-value of 0.043 . Since the prediction that market reacts positively to tone is directional, the one-tailed p-value demonstrates that this association is significant at 5\% level. Column 2 and 3 show that Narcissism is not directly significantly associated with $\operatorname{CAR}(-1,1)$, and that its inclusion in the regression does not qualitatively change the effect of tone on market reaction. In column 4 of Table 6, while the coefficient of Tone remains positive and statistically significant, the interaction term between Tone and Narcissism has a negative coefficient of 0.0058 , with a t-value of -1.76 and a one-tailed p-value of 0.039 . This indicates that while the market reacts positively to tone of earnings announcements, the investors nonetheless are aware of the effect of CEO narcissism on tone, and discount their reaction accordingly. This moderation effect of CEO narcissism on market reaction echoes prior studies, which find a negative moderation effect of CEO equity-based compensation on market reaction to tone (Arslan-Ayaydin et al. 2016), and a positive moderation effect of managerial ability on market reaction to tone (Luo and Zhou 2017).

\subsection{Robustness Analyses}

\subsubsection{CEO Dispositional Optimism}

Davis et al. (2015) document that CEO dispositional optimism is associated with more positive tone in earnings conference calls. While this paper investigates a different CEO trait, namely narcissism, we do strive to control for CEO dispositional optimism. For example, Davis et al. (2015) propose that female CEOs and older CEOs would have more negative tone, although they fail to support these conjectures using the tone measure based on Loughran and McDonald (2011). We nonetheless control for Gender and Age, and find that CEO gender does play a role in earnings announcements tone. Davis et al. (2015) also report that CEOs who begin their careers in a recession year are more likely to have conservative 
tone; this paper finds similar results. In addition, Davis et al. (2015) collect information on CEO's involvement in charitable organizations, citing that such individuals are more likely to be optimistic (Mellor et al. 2008).

In order to further control for CEO dispositional optimism, this study follows Davis et al. (2015) and collects information from FactSet on whether or not the sample executives are on the board of any nonprofit organization; individuals who are actively involved in charitable work are assumed to be happier and more optimistic (Davis et al. 2015). Charity is coded 1 if a CEO serves on the board of a non-profit organization, and 0 otherwise. We include Charity into Equation (1) and (2), perform tests, and report results in Table 7. These results are presented as robustness tests due to a potential weakness of the proxy Charity. Specifically, since we collect Charity information ex post facto, it is unclear to us whether the CEOs are involved in the non-profit organizations before or after the sample periods. In terms of summary statistics, the mean of Charity is 0.86 with a median of 1 and a standard deviation of 0.35 .

As shown in Table 7, Charity is positively and statistically significantly associated with Tone across all models. This concurs to the results of Mellor et al. (2008) as well as those documented by Davis et al. (2015). Despite Charity being included in the model, Narcissism is still positively and statistically significantly associated with Tone, with a coefficient of 0.023 and a t-value of 2.09 in column (3) of Table 7. Column (4) of Table 7 shows that CEO age negatively and significantly moderates the effect of narcissism on tone, with a coefficient of -0.005 and a t-value of -2.54 . Overall, our main results hold even after controlling for Charity.

Table 7 Results including Charity as control for CEO dispositional optimism

\begin{tabular}{|c|c|c|c|c|c|}
\hline & VIF & 1 & 2 & 3 & 4 \\
\hline Narcissism & 1.60 & & $\begin{array}{c}0.022 * * \\
(2.00)\end{array}$ & $\begin{array}{c}0.022 * * \\
(2.09)\end{array}$ & $\begin{array}{c}0.341 * * * \\
(2.71)\end{array}$ \\
\hline Narcissism $x$ Age & & & & & $\begin{array}{c}-0.005 * * \\
(-2.54)\end{array}$ \\
\hline Age & 1.53 & & & -0.002 & $-0.003 *$ \\
\hline
\end{tabular}


Table 7 Results including Charity as control for CEO dispositional optimism

\begin{tabular}{|c|c|c|c|c|c|}
\hline & VIF & 1 & 2 & 3 & 4 \\
\hline & & & & $(-1.52)$ & $(-1.69)$ \\
\hline \multirow[t]{2}{*}{ Gender } & 1.39 & $0.137 * *$ & $0.142 * *$ & $0.137 * *$ & $0.149 * *$ \\
\hline & & $(2.08)$ & $(2.15)$ & $(2.06)$ & $(2.25)$ \\
\hline \multirow[t]{2}{*}{ Recession } & 1.08 & $-0.038^{*}$ & -0.036 & $-0.040^{*}$ & $-0.043 *$ \\
\hline & & $(-1.67)$ & $(-1.61)$ & $(-1.80)$ & $(-1.92)$ \\
\hline \multirow[t]{2}{*}{ Confidence } & 1.99 & -0.015 & -0.015 & -0.015 & -0.015 \\
\hline & & $(-0.79)$ & $(-0.77)$ & $(-0.77)$ & $(-0.78)$ \\
\hline \multirow[t]{2}{*}{ Charity } & 1.51 & $0.081 * * *$ & $0.077 * * *$ & $0.072 * * *$ & $0.068 * * *$ \\
\hline & & $(3.49)$ & $(3.31)$ & $(3.09)$ & $(2.93)$ \\
\hline Control Variables & & Yes & Yes & Yes & Yes \\
\hline Year Fixed Effects & & Yes & Yes & Yes & Yes \\
\hline Quarter Fixed Effects & & Yes & Yes & Yes & Yes \\
\hline Industry Fixed Effects & & Yes & Yes & Yes & Yes \\
\hline \multirow[t]{2}{*}{ Constant } & & $0.904^{* * *}$ & $0.879 * * *$ & $0.972 * * *$ & $0.873 * * *$ \\
\hline & & $(2.83)$ & $(2.75)$ & $(2.97)$ & $(2.66)$ \\
\hline Observations & & 3,377 & 3,377 & 3,377 & 3,377 \\
\hline Adjusted R2 & & 0.162 & 0.163 & 0.163 & 0.165 \\
\hline
\end{tabular}

Notes. Models in Table 7 are OLS models with robust errors. The dependent variable in all models is Tone. Tone accounts for the tone of quarterly earnings announcement and it is defined as $100 *$ (Positive word count - Negative word count) divided by the total word count of the quarterly earnings announcement. Model 1shows the effect of the set variables controlling for CEO dispositional optimism. Gender equals 1 if the CEO is female, and 0 if male.

Recession equals 1 if there is a recession when the CEO is 22 years old and, 0 otherwise. Confidence equals 1 if the CEO Confidence Index is equal or larger than 50, and zero otherwise. Charity equals 1 if the CEO is a member of the board of at least one non-profit organization, and 0 otherwise. Model 2 includes Narcissism, which is a composite measure of CEO narcissism resulting from a factor analysis using the CEO photo size, relative cash pay and relative non-cash pay. Model 3 adds $A g e$, which is the CEO age in years. Model 4 shows the interaction between Narcissim and Age. All models include control variables (i.e., Wealth, Size, Surp, EPS, ROA, Loss, LeadROA, MTB, Nanalyst and Risk) as well as year, quarter, and industry fixed effects. To the right of the models is presented the Variance Inflation Factor (VIF) as a multicollinearity indicator. Estimators of each variable are reported on the top row, and Z-test values appear in brackets below each coefficient.

* Significance at the $10 \%$ level; ** significance at the $5 \%$ level; *** significance at the $1 \%$ level.

\subsubsection{Firm Fixed Effects}

In the main tests presented in Table 5, this paper controls for industry, year, and quarter fixed effects, similar to the model employed by Olsen et al. (2014). An alternative model would also control for firm fixed effects (e.g., Olsen and Stekelberg 2016). Among the final sample of 215 firms in this study, there is one firm that employs three CEOs and 63 firms that employ two CEOs during the sample period; all the other 151 firms have only one CEO during the sample periods. Due to this innate characteristic of 
the sample, to control for firm fixed effects in these 215 firms would largely equate with controlling for CEO fixed effects, which would then take away the explanation power of Narcissism. Nevertheless, in order to exclude any firm fixed effects that may potentially drive the empirical results in Table 5, we substitute the industry fixed effects in Equation (2) with firm fixed effects, and conduct the regression on a sub-sample of 64 firms that employ more than one CEO during the sample periods. The sub-sample contains 1,147 firm-CEO-quarter observations, and the results are presented in Table 8.

Column (2) of Table 8 shows that Narcissism is positively and significantly associated with Tone, with a coefficient of 0.076 and a t-statistic of 3.07. Further, column (3) shows a coefficient of 0.698 and a t-value of 2.07 on Narcissism, and the interaction between Narcissism and Age has a coefficient is -0.010 and t-value of -1.80 . These results demonstrate that the effect of CEO narcissism on tone of earnings announcements and the moderation effect of CEO age are unlikely to be driven by any firm characteristics.

Table 8 Results with firm fixed effects (firms with more than one CEO during the time span of the study)

\begin{tabular}{lcccc}
\hline & VIF & 1 & 2 & 3 \\
\hline Narcissism & & & & \\
& 4.39 & $0.076^{* * *}$ & $0.076^{* * *}$ & $0.698^{* *}$ \\
Narcissism Age & & $(3.07)$ & $(3.07)$ & $(2.07)$ \\
& & & & $-0.010^{*}$ \\
Age & & & $(-1.80)$ \\
& 2.81 & & 0.0004 & 0.0004 \\
Firm-level Control Variables & & & $(0.13)$ & $(0.12)$ \\
Manager-level Control Variables & & Yes & Yes & Yes \\
Year Fixed Effects & & Yes & Yes & Yes \\
Quarter Fixed Effects & & Yes & Yes & Yes \\
Firm Fixed Effects & & Yes & Yes & Yes \\
Constant & & Yes & Yes & Yes \\
& & 0.745 & 0.699 & 0.697 \\
Observations & $(1.29)$ & $(1.12)$ & $(1.14)$ \\
Adjusted R & & & \\
Nos. & & 1,147 & 1,147 \\
\hline
\end{tabular}

Notes. Models in Table 8 are OLS models with robust errors. The models are estimated for the subsample of firms that had more than one CEO during the time span of the study. The dependent variable in all models is Tone. Tone accounts for the tone of quarterly earnings announcement and it is defined as $100 *$ (Positive word count - Negative 
word count) divided by the total word count of the quarterly earnings announcement. Model 1shows the effect of Narcissism, which is a composite measure of CEO narcissism resulting from a factor analysis using the CEO photo size, relative cash pay and relative non-cash pay. Model 2 adds Age, which is the CEO age in years. Model 3 shows the interaction between Narcissim and Age. All models include the set of firm-level control variables (i.e., Size, Surp, EPS, ROA, Loss, LeadROA, MTB, Nanalyst and Risk), the set of manger-level control variables (i.e., Wealth, Gender, Recession, and Confidence) as well as year, quarter, and firm fixed effects. To the right of the models is presented the Variance Inflation Factor (VIF) as a multicollinearity indicator. Estimators of each variable are reported on the top row, and Z-test values appear in brackets below each coefficient.

* Significance at the $10 \%$ level; ** significance at the $5 \%$ level; *** significance at the $1 \%$ level.

\section{Conclusions}

Narcissistic individuals have a constant need to reinforce their grandiose self-image. To obtain this reinforcement, narcissists tend to show a positive bias when evaluating and describing their performance. Based on this notion, we propose that CEO narcissism (considered as a continuous dimension) is likely to have a positive effect on the tone of a firm's earnings announcements. We also claim that this effect is likely to be less salient in companies led by an older CEO given that some personality features that can reduce the exaggerated positive self-view attributed to narcissism (e.g., humility and conscientiousness) are likely to develop with age. Therefore, we claim that age moderates the relation between CEOs' narcissism and the tone of the earnings announcements. We test these theoretical expectations in a sample of Fortune 500 companies with 3,370 firm-quarter observations from 1996 to 2014 . To conduct the empirical tests, we calculate an indirect measure of narcissism following Olsen et al. (2014). The empirical results support our expectations. We find that, after controlling for several tone determinants, the tone of the earnings announcements tends to be more positive in companies managed by a more narcissistic CEO and that this positive effect is less salient in firms lead by an older CEO.

Prior research shows that financial markets react to the tone of earnings announcements. However, the literature on determinants of tone remains limited. We contribute to this literature by providing evidence that CEO narcissism generates a positive bias in the tone of earnings announcements and hence, market agents need to consider this factor in order to enhance their capacity to interpret and process the information disclosed in earnings announcements. Indeed, we document that while the stock market reacts positively to tone of earnings announcements, this positive reaction is moderated by CEO narcissism. Moreover, in the 
last two decades, narcissism seems to have an increasing trend among CEOs and general population (e.g., Campbell and Campbell 2009; Engelen et al. 2016; Young et al. 2016). Thus, understanding the impact of this specific construct (i.e., narcissism) in firm decisions and practices is critical in understanding the behavior of companies in the forthcoming years.

Our work is not free from limitations. We share limitations of previous accounting research exploring the effect of narcissism in other firm decisions. Firstly, due to data restrictions, we use an indirect measure of narcissism based on secondary data (i.e., observable outcomes). Ideally, research on the effect of CEO narcissism on firm outcomes should use a more direct measure of narcissism, such as the Narcissistic Personality Inventory (NPI). In the same vein, future research could use textual analysis to develop new non-invasive measures of narcissism by based on the way in which CEOs structure their speeches and letters addressed to stockholders. Secondly, narcissism is likely to be related to other personality traits such as overconfidence and dispositional optimism and therefore, fully disentangling the effect of these three variables is a complicated task. Nevertheless, given that our empirical measure of narcissism is specifically computed based on some observable outcomes that characterize narcissistic behavior (Olsen et al, 2014) and the fact that we use control variables accounting for dispositional optimism provide us with confidence that our results are showing the effect of narcissism on CEOs' tone preferences. Finally, because we conduct this paper using a sample of firms listed in the Fortune 500 list, the generalization of our results to small and private firms should be taken with caution. 


\section{References}

Adams, R. B., \& Funk P. (2012). Beyond the Glass Ceiling: Does Gender Matter? Management Science, $58(2), 219-235$.

Amernic, J., \& Craig R. (2010). Accounting as a facilitator of extreme narcissism. Journal of Business Ethics, 96 (1), 79-93.

Arslan-Ayaydin, Ö., Boudt K., \& Thewissen J. (2016). Managers set the tone: Equity incentives and the tone of earnings press releases. Journal of Banking \& Finance, 72 (supplement), s132-s147.

Ashton, M. C., \& Lee, K. (2016). Age trends in HEXACO-PI-R self-reports. Journal of Research in Personality, 64, 102-111.

Berger, A. N., Kick T., \& Schaeck K. (2014). Executive board composition and bank risk taking. Journal of Corporate Finance, 28, 48-65.

Blickle, G., Schlegel A., Fassbender P., \& Klein U. (2006). Some personality correlates of business white-collar crime. Applied Psychology, 55 (2), 220-233.

Brown, R.P., Budzek K., \& Tamborski M. (2009). On the meaning and measure of narcissism. Personality and Social Psychology Bulletin, 35 (7), 951-964.

Campbell, W. K., Reeder, G. D., Sedikides, C., \& Elliot, A. J. (2000). Narcissism and comparative selfenhancement strategies. Journal of Research in Personality, 34(3), 329-347.

Campbell, W. K., Goodie A. S., \& Foster J. D. (2004). Narcissism, confidence, and risk attitude. Journal of Behavioral Decision Making. 17 (4), 297-311.

Campbell, W.K., \& Campbell S.M. (2009). On the self-regulatory dynamics created by the peculiar benefits and costs of narcissism: A contextual reinforcement model and examination of leadership. Self and Identity. 8 (2-3), 214-232.

Campbell, W.K., \& Siedor, L. (2016). Cheating, corruption, and concealment. Cambridge University Press, 151-165.

Chatterjee, A., \& Hambrick D. C. (2007). It's all about me: Narcissistic chief executive officers and their effects on company strategy and performance. Administrative Science Quarterly, 52 (3), 351-386.

Chatterjee, A., \& Hambrick D. C. (2011). Executive personality, capability cues, and risk taking how narcissistic CEOs react to their successes and stumbles. Administrative Science Quarterly, 56 (2), 202237.

Clatworthy, M., \& Jones M. J. (2003). Financial reporting of good news and bad news: Evidence from accounting narratives. Accounting and Business Research. 33 (3), 171-185.

Davis, A.K., Ge W., Matsumoto D., \& Zhang J. L. (2015). The effect of manager-specific optimism on the tone of earnings conference calls. Review of Accounting Studies, 20 (2), 639-673. 
Davis, A.K., Piger J.M., \& Sedor L.M. (2012). Beyond the numbers: Measuring the information content of earnings press release language. Contemporary Accounting Research, 29 (3), 845-868.

Davis, A.K., \& Tama-Sweet I. (2012). Managers' use of language across alternative disclosure outlets: Earnings press releases versus MD\&A. Contemporary Accounting Research, 29 (3), 804-837.

Emmons, R. A. (1987). Narcissism: Theory and measurement. Journal of Personality and Social Psychology, 52, 11-17.

Engelen, A., Neumann C., \& Schmidt S. (2016). Should entrepreneurially oriented firms have narcissistic CEOs? Journal of Management, 42 (3), 698-721.

Farwell, L., \& Wohlwend-Lloyd R. (1998). Narcissistic Processes: Optimistic expectations, favorable self-evaluations, and self-enhancing attributions. Journal of Personality, 66 (1), 65-83.

Feldman, R., Govindaraj S., Livnat J., \& Segal B. (2010). Management's tone change, post earnings announcement drift and accruals. Review of Accounting Studies, 15 (4), 915-953.

Foster, J.D., Campbell W.K., \& Twenge J.M. (2003). Individual differences in narcissism: Inflated selfviews across the lifespan and around the world. Journal of Research in Personality, 37(6), 469-486.

Francis, B., Hasan I., Park J. C., \& Wu Q. (2015). Gender differences in financial reporting decision making: Evidence from accounting conservatism. Contemporary Accounting Research, 32(3), 1285-1318.

Gabriel, M. T., Critelli J. W., \& Ee J. S. (1994). Narcissistic illusions in self-evaluations of intelligence and attractiveness. Journal of Personality, 62 (1), 143-155.

Gerstner, W., König A., Enders A., \& Hambrick D.C. (2013). CEO narcissism, audience engagement, and organizational adoption of technological discontinuities. Administrative Science Quarterly, 58 (2), 257291.

Ham, C., Lang, M., Seybert, N., \& Wang, S. (2017). CFO narcissism and financial reporting quality, Journal of Accounting Research.

Hambrick, D.C., \& Mason P. A. (1984). Upper echelons: The organization as a reflection of its top managers. Academy of Management Review, 9(2), 193-206.

Henry, E. (2008). Are investors influenced by how earnings press releases are written? Journal of Business Communication, 45 (4), 363-40.

Hickman, S. E., Watson P. J., \& Morris R. J. (1996). Optimism, pessimism, and the complexity of narcissism. Personality and Individual Differences, 20 (4), 521-525.

Ho, S., Li A., Tam K., \& Zhang F. (2015). CEO gender, ethical leadership, and accounting conservatism. Journal of Business Ethics. 127(2), 351-370.

Horvath, S., \& Morf, C. C. (2010). To be grandiose or not to be worthless: Different routes to selfenhancement for narcissism and self-esteem. Journal of Research in Personality, 44(5), 585-592. 
Hoyle, R. H. (2010). Personality and self-regulation (pp. 1-18). Wiley-Blackwell.

Huang, X., Teoh S. H., \& Zhang Y. (2014). Tone management. The Accounting Review, 89 (3), 10831113.

Jegadeesh, N., \& Wu D. (2013). Word power: A new approach for content analysis. Journal of Financial Economics, $110(3), 712-729$.

John, O. P., \& Robins R. W. (1994). Accuracy and bias in self-perception: individual differences in selfenhancement and the role of narcissism. Journal of Personality and Social Psychology, 66 (1), 206 -219.

Khan, W. A., \& Vieito J. P. (2013). CEO gender and firm performance. Journal of Economics \& Business, 67, 55-66.

Li, F. (2010). The information content of forward-looking statements in corporate filings-A naïve bayesian machine learning approach. Journal of Accounting Research, 48 (5), 1049-1102.

Liu, B., \& McConnell J.J. (2013). The role of the media in corporate governance: Do the media influence managers' capital allocation decisions? Journal of Financial Economics, 110 (1), 1-17.

Loughran, T., \& McDonald B. (2011). When is a liability not a liability? Textual analysis, dictionaries, and 10-Ks. The Journal of Finance, 66 (1), 35-65.

Loughran, T., \& McDonald B. (2014). Measuring readability in financial disclosures. The Journal of Finance. 69 (4), 1643-1671.

Luo, Y., \& Zhou L. (2017). Managerial ability, tone of earnings announcements, and market reaction. Asian Review of Accounting, 25(4), 454-471.

Majors, T. M. (2016). The interaction of communicating measurement uncertainty and the dark triad on managers' reporting decisions. The Accounting Review, 91 (3), 973-992.

Mellor, D., Hayashi, Y., Firth, L., Stokes, M., Chambers, S., \& Cummins, R. (2008). Volunteering and well-being: do self-esteem, optimism, and perceived control mediate the relationship? Journal of Social Service Research, 34(4), 61-70.

Ng, E. S., \& Sears G.J. (2017). The glass ceiling in context: the influence of CEO gender, recruitment practices and firm internationalisation on the representation of women in management. Human Resource Management Journal, 27(1), 133-151.

Olsen, K. J., \& Stekelberg J. (2016). CEO narcissism and corporate tax sheltering. The Journal of the American Taxation Association, 38 (1), 1-22.

Olsen, K. J., Dworkis K. K., \& Young S. M. (2014). CEO narcissism and accounting: A picture of profits. Journal of Management Accounting Research, 26 (2), 243-267.

O'Reilly III, C. A., Doerr, B., \& Chatman, J. A. (2017). "See You in Court”: How CEO narcissism increases firms' vulnerability to lawsuits, The Leadership Quarterly. 
Owens, B. P., Wallace, A. S., \& Waldman, D. A. (2015). Leader narcissism and follower outcomes: The counterbalancing effect of leader humility. Journal of Applied Psychology, 100(4), 1203.

Petrenko, O. V., Aime F., Ridge J., \& Hill A. (2016). Corporate social responsibility or CEO narcissism? CSR motivations and organizational performance. Strategic Management Journal, 37 (2), 262-279.

Prendergast, C., \& Stole L. (1996). Impetuous youngsters and jaded old-timers: Acquiring a reputation for learning. Journal of Political Economy, 104, 1105-1134.

Price, S. M., Doran J. S., Peterson D. R., \& Bliss B. A. (2012). Earnings conference calls and stock returns: The incremental informativeness of textual tone. Journal of Banking and Finance, 36 (4), 9921011.

Raskin, R., \& Terry H. (1988). A principal-components analysis of the Narcissistic Personality Inventory and further evidence of its construct validity. Journal of Personality and Social Psychology, 54 (5), 890902.

Rhodewalt, F., \& Morf C. C. (1995). Self and interpersonal correlates of the Narcissistic Personality Inventory: A review and new findings. Journal of Research in Personality, 29 (1), 1-23.

Rhodewalt, F., \& Morf C. C. (1998). On self-aggrandizement and anger: a temporal analysis of narcissism and affective reactions to success and failure. Journal of Personality and Social Psychology, $74(3), 672-685$.

Roberts, B. W., Jackson, J. J., Fayard, J. V., Edmonds, G., \& Meints, J. (2009). Conscientiousness. In M. Leary \& R. Hoyle (Eds.), Handbook of individual differences in social behavior (pp. 369-381). New York, NY: Guilford Press.

Roberts, B. W., Lejuez, C., Krueger, R. F., Richards, J. M., \& Hill, P. L. (2014). What is conscientiousness and how can it be assessed? Developmental Psychology, 50(5), 1315.

Rogers, J. L., Buskirk A. V., \& Zechman S. C. (2011). Disclosure tone and shareholder litigation. The Accounting Review, 86 (6), 2155-2183.

Scheier, M., \& Carver C. (1993). On the power of positive thinking: the benefits of being optimistic. Current Directions in Psychological Science, 2(1), 26-30.

Schoar, A., \& Zuo, L. (2016). Does the Market Value CEO Styles?. American Economic Review, 106(5), 262-266.

Schleicher, T., \& Walker M. (2010). Bias in the tone of forward-looking narratives, Accounting and Business Research. 40 (4), 371-390.

Serfling, M. A. (2014). CEO age and the riskiness of corporate policies. Journal of Corporate Finance, $25,251-273$.

Stice, E. K. (1991). The market reaction to 10-K and 10-Q filings and to subsequent The Wall Street Journal earnings announcements. The Accounting Review, 66 (1), 42-55. 
Twedt, B., \& Rees L. (2012). Reading between the lines: An empirical examination of qualitative attributes of financial analysts' reports. Journal of Accounting and Public Policy, 31 (1), 1-21.

Twenge, J. M., \& Campbell, S. M. (2008). Generational differences in psychological traits and their impact on the workplace. Journal of Managerial Psychology, 23(8), 862-877.

Young, S. M., Du F., Dworkis K. K., \& Olsen K. J. (2016). It's all about all of us: The rise of narcissism and its implications for management control system research. Journal of Management Accounting Research, 28 (1), 39-55.

Zhang, H., Ou, A.Y., Tsui, A.S. and Wang, H., 2017. CEO humility, narcissism and firm innovation: A paradox perspective on CEO traits. The Leadership Quarterly, 28(5): 585-604. 


$\begin{array}{ll}\text { APPENDIX Variable Definitions } \\ \text { Variable } & \end{array}$

